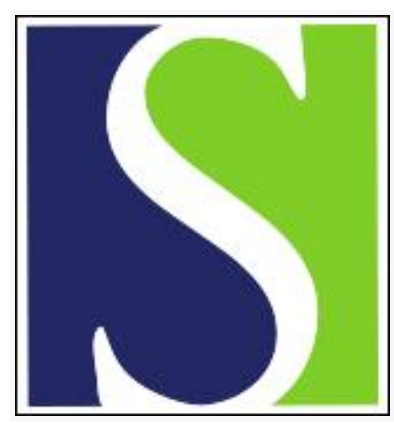

Scand J Work Environ Health 1976;2(3):147-151

https://doi.org/10.5271/sjweh.2813

Issue date: Sep 1976

A study on the mutagenic activity of styrene and styrene oxide.

by Vainio H, Pääkkönen R, Rönnholm K, Raunio V, Pelkonen 0

The following article refers to this text: 1979;5(2):162-163

Key terms: metabolic activation; microsome; mutagenic activity; mutation; styrene; styrene oxide

This article in PubMed: www.ncbi.nlm.nih.gov/pubmed/788148

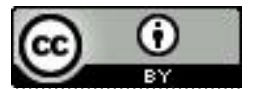




\title{
A study on the mutagenic activity of styrene and styrene oxide ${ }^{1}$
}

\author{
by HARRI VAINIO, M.D., ${ }^{2}$ RAIJA PÄÄKKÖNEN, M.Sc., ${ }^{3}$ KAI RÖNNHOLM, B.M.,3 \\ VEIJO RAUNIO, M.D., 3 and OLAVI PELKONEN, M.D. ${ }^{4}$
}

\begin{abstract}
VAINIO, H., PÄÄKKÖNEN, R., RÓNNHOLM, K., RAUNIO, V. and PELKONEN, O. A study on the mutagenic activity of styrene and styrene oxide. Scand. $j$. work environ. \& health 3 (1976) 147-151. Styrene oxide is mutagenic, without metabolic activation, to $\mathrm{S}$. typhimurium strains TA 1535 and TA 100, which have been devised to detect mutagens causing base-pair substitutions. Styrene seems to be mutagenic toward the same strains, but only after metabolic activation. The toxicity of both styrene and styrene oxide make the construction of reliable doseresponse curves rather difficult. Diethylmaleate and 3,3,3-trichloropropene oxide enhanced the mutagenicity of styrene oxide in the presence of homogenate; this result indicates the participation of epoxide hydratase and glutathione S-oxide transferase in the metabolism of styrene oxide. These two chemicals did not influence the mutagenic activity of styrene. Styrene glycol and 4-tert.-butylbrenzcatechin were not mutagenic to any of the strains studied. Results show that further, more detailed experimental and, possibly, epidemiologic studies are warranted.
\end{abstract}

Key words: mutations, styrene, metabolic activation, microsomes.

Styrene is widely used in the plastic industry. Styrene is converted by liver microsomes to its epoxide, styrene oxide, which is further metabolized by epoxide hydratase to styrene glycol (5).

Structurally, styrene, i.e., vinylbenzene, is related to vinyl chloride, a compound known for its carcinogenic potential in man

1 A preliminary communication was presented at the Mutagenesis-Drug Metabolism Conference, held in Research Triangle Park, N.C., U.S.A., 9-1I February 1976.

2 Department of Industrial Hygiene and Toxicology, Institute of Occupational Health, Helsinki, Finland.

3 Department of Microbiology, University of Oulu, Oulu, Finland.

4 Department of Pharmacology, University of Oulu, Oulu, Finland.

Reprint requests to: Dr. Harri Vainio, Institute of Occupational Health, Haartmaninkatu 1, FIN-00290 Helsinki 29, Finland. and animals (4). In in vitro experiments vinyl chloride is metabolized by liver microsomes to a compound which is mutagenic to Salmonella typhimurium bacteria (histidine auxotrophs) strains (9) developed by Ames and coworkers for the detection of mutagenic compounds $(1,2)$.

Because of the wide use of styrene and its resemblance to vinyl chloride we decided to study the mutagenic potential of styrene and its metabolites in the Salmonella system, both in the presence and in the absence of liver microsomal enzymes.

\section{MATERIALS AND METHODS}

\section{Mutagenicity testing}

Specially constructed mutants of Salmonella typhimurium, selected for their sen- 
Table 1. Mutagenicity of styrene oxide to Salmonella typhimurium. (- indicates the absence and + the presence of $0.1 \mathrm{ml}$ of S-9 per plate)

\begin{tabular}{|c|c|c|c|c|c|c|c|c|c|c|}
\hline $\begin{array}{l}\text { Concentration of } \\
\text { styrene oxide } \\
\text { moles/plate }\end{array}$ & $\frac{\text { TA }}{-}$ & $\begin{array}{c}1535 \\
+\end{array}$ & $\stackrel{\text { TA }}{-}$ & $\begin{array}{c}1537 \\
+\end{array}$ & TA & $\begin{array}{c}1538 \\
+\end{array}$ & $\underline{\mathrm{TA}}$ & $\begin{array}{c}100 \\
+\end{array}$ & $\underline{\mathrm{Ta}}^{\mathrm{T}}$ & $\begin{array}{r}98 \\
+\end{array}$ \\
\hline $10^{-4}$ & \multicolumn{2}{|c|}{ toxic } & \multicolumn{2}{|c|}{ toxic } & \multicolumn{2}{|c|}{ toxic } & \multicolumn{2}{|c|}{ toxic } & \multicolumn{2}{|c|}{ toxic } \\
\hline $10^{-5}$ & 357 & 484 & 8 & 8 & 11 & 32 & 1111 & 1165 & 25 & 26 \\
\hline $10^{-6}$ & 425 & 468 & 6 & 8 & 7 & 35 & 443 & 639 & 26 & 16 \\
\hline $10^{-7}$ & 249 & - & - & - & 9 & 16 & 217 & 146 & 16 & 16 \\
\hline $10^{-8}$ & 124 & - & - & - & 5 & 12 & 240 & 142 & 8 & 19 \\
\hline $10^{-9}$ & 19 & 18 & - & - & 7 & 9 & 115 & 108 & 11 & 13 \\
\hline 0 & 20 & 45 & 7 & 4 & 9 & 7 & 84 & 135 & 26 & 21 \\
\hline
\end{tabular}

Table 2. Mutagenicity of styrene to Salmonella typhimurium. ( - indicates the absence and + the presence of $0.1 \mathrm{ml}$ of $\mathrm{S}-9$ per plate)

\begin{tabular}{|c|c|c|c|c|c|c|c|c|c|c|}
\hline $\begin{array}{l}\text { Concentration of } \\
\text { styrene moles/plate }\end{array}$ & $\underline{\mathrm{TA}}$ & $\begin{array}{c}1535 \\
+\end{array}$ & $\underline{\mathrm{TA}}$ & $\begin{array}{c}1537 \\
+\end{array}$ & TA & $\begin{array}{c}1538 \\
+\end{array}$ & $\mathrm{T}$ & $\begin{array}{c}100 \\
+\end{array}$ & $\underline{\mathrm{Ta}}$ & $\begin{array}{l}98 \\
+\end{array}$ \\
\hline $\begin{array}{l}10^{-4} \\
10^{-5}\end{array}$ & \multicolumn{2}{|c|}{ toxic } & \multicolumn{2}{|c|}{ toxic } & \multicolumn{2}{|c|}{ toxic } & \multicolumn{2}{|c|}{ toxic } & \multicolumn{2}{|c|}{ toxic } \\
\hline $10^{-6}$ & 13 & 16 & 7 & 11 & 8 & 10 & 197 & 206 & 21 & 24 \\
\hline $10^{-7}$ & 20 & 84 & 12 & 12 & - & - & 56 & 78 & - & - \\
\hline $10^{-8}$ & 22 & 112 & - & - & - & - & 115 & 163 & - & 一 \\
\hline 0 & 17 & 16 & 7 & 12 & 9 & 7 & 83 & 97 & 24 & 13 \\
\hline
\end{tabular}

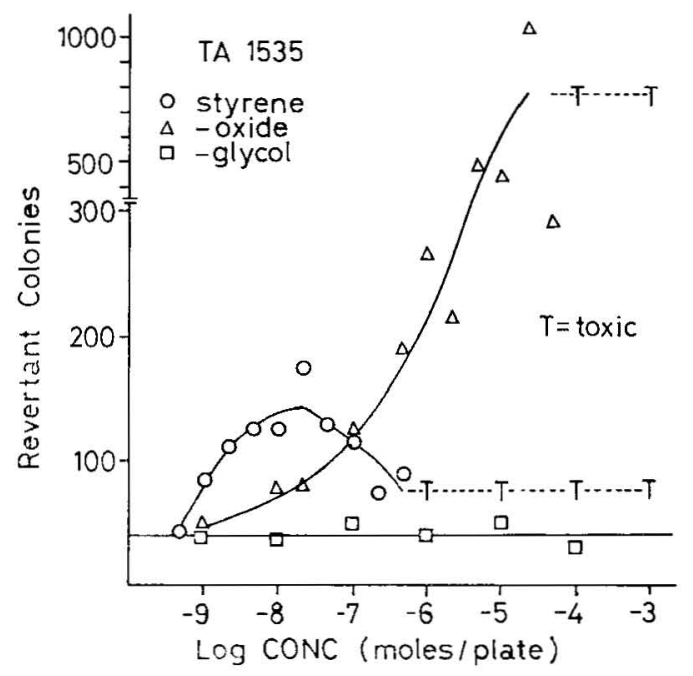

Fig. 1. Mutagenic effect of styrene, styrene oxide, and styrene glycol on strain TA 1535. The mutagenicity of styrene and styrene glycol were tested in the presence of and styrene oxide in the absence of S-9 fraction $(0.1 \mathrm{ml} /$ plate). sitivity and specificity in being reverted from a histidine requirement back to prototrophy by a wide variety of mutagens, were used in the study $(1,2,6)$. Strains TA 1535, TA 1537, TA 1538, TA 98, and TA 100 were kindly provided by Dr. Bruce N. Ames (Berkeley, Calif.). Diagnostic tests were those described by Ames et al. (3).

Styrene or styrene oxide (both obtained from Koch-Light Laboratories Ltd., Colnbrook England) was dissolved in absolute ethanol, put with a top agar, enzyme preparation and a cofactor mixture when appropriate into petri plates, and incubated for 2 days at $+37^{\circ} \mathrm{C}$, after which the number of revertant colonies were calculated. Both direct (without enzyme preparation) and indirect mutagenesis (with enzyme and cofactors) assays were performed. Spot tests were also performed after the addition of the compound to a small filter paper disc in the center of a petri plate and bacteria with other constituents. This test could not be per- 
formed with styrene because obviously styrene does not diffuse from the filter paper, or from the spot if added without filter paper.

\section{Enzyme preparation}

Male rats (200 to $300 \mathrm{~g}$ ) of the SpragueDawley strain were injected with a polychlorinated biphenyl compound, Clophen C $(200 \mathrm{mg} / \mathrm{kg}$, obtained from Bayer AG, Leverkusen) in sesame oil 5 days before they were killed. Livers were removed, homogenized in four volumes of $0.15 \mathrm{M}$ $\mathrm{KCl}$, and centrifuged at $10,000 \times \mathrm{g}$ for 10 min. The supernatant fraction ("S-9") was divided into $2-\mathrm{ml}$ fractions and stored at $-80^{\circ} \mathrm{C}$ until used.

\section{RESULTS}

Tables 1 and 2 show the preliminary screening of the mutagenic potential of styrene oxide and styrene over a wide range of concentrations. As can be seen, both styrene oxide and styrene were toxic to all strains at high concentrations, styrene oxide at about $10^{-4}$ moles/plate and above and styrene at about $10^{-6}$ moles/ plate and above. This high toxicity made the mutagenicity determinations at this range of concentration difficult. However, as table 1 shows, styrene oxide was clearly mutagenic to two of the five strains, namely, to TA 1535 and TA 100 . It was not mutagenic to TA 1537 , 1538, or 98. The enzyme preparation did not remarkably affect the mutation rate, and this finding suggests that we were dealing with a direct mutagen. On the other hand, the preliminary screening with styrene showed (table 2) that it may be mutagenic to TA 1535 and TA 100 . However, a more detailed dose-response study with TA 1535 revealed that styrene may be both an indirect and direct mutagen, although results suggest that the considerable toxicity of styrene disturbs the interpretation of results obtained from concentrations as low as about $10^{-7}$ moles/plate (fig. 1) A similar study with styrene and TA 100
Table 3. Effect of diethylmaleate (DEM) and 3,3,3-trichloropropene oxide (TCPO) (both at $1 \mathrm{mmol} / 1$ concentration) on the mutagenicity of styrene oxide and styrene. The amount of $\mathrm{S}-9$ is $0.1 \mathrm{ml} /$ plate when present.

\begin{tabular}{lrrrr}
\hline & \multicolumn{3}{c}{ Revertant colonies (TA 1535) } \\
& $-\mathrm{S}-9$ & $+\mathrm{S}-9$ & \multicolumn{1}{c}{$+\mathrm{S}-9 \begin{array}{r}\text { +S-9 } \\
+ \text { TCPO }\end{array}$} \\
& & & & \\
& & & & \\
\hline Styrene oxide & & & & \\
$\quad 10^{-5} \mathrm{~mol} /$ plate & 233 & 116 & 231 & 244 \\
$\quad$ control & 22 & 14 & 19 & 16 \\
$\begin{array}{l}\text { Styrene } \\
5 \times 10^{-8}\end{array}$ & & & & \\
$\begin{array}{l}\text { mole/plate } \\
\text { control }\end{array}$ & 52 & 112 & 146 & 132 \\
& 36 & 41 & 21 & 34 \\
\hline
\end{tabular}

gave more equivocal results. A doseresponse study with styrene oxide and TA 100 revealed that styrene oxide is a direct mutagen. Spot tests demonstrated that styrene oxide is mutagenic to TA 1535 and TA 100, but not to TA 1537, TA 1538 and TA 98 , and thus confirmed the results of the plate incorporation assays. Styrene could not be studied with spot tests, because of its solubility and diffusion characteristics in agar.

Diethylmaleate, a compound which is known to deplete cytoplasmic glutathione, and 3,3,3-trichloropropene oxide, an inhibitor of epoxide hydratase (8), slightly increased the mutation rate caused by styrene (table 3). At the concentration used and in the presence of the S-9 fraction, diethylmaleate and trichloropropene oxide had no effect on the mutation rate of the strains studied.

The ratio styrene oxide/homogenate, when added, affects greatly the data obtained. Larger amounts of the liver homogenate seem to protect the bacteria, perhaps due to the presence of the enzymes glutathione S-transferase and epoxide hydratase, which metabolize styrene oxide. The protective effect could be abolished by diethylmaleate and trichloropropene oxide (table 3 ).

Styrene glycol did not exhibit mutagenicity towards TA 1535 and TA 100 in the concentration range from $10^{-4}$ to $10^{-10}$ moles/plate. In addition the preservation agent, 4-tert.-butyl-brenzcatechin, was not mutagenic to any of the five strains used. 


\section{DISCUSSION}

Earlier studies have demonstrated that styrene is converted by microsomal monooxygenase systems to styrene oxide, which is metabolized further by epoxide hydratase to styrene glycol (5). Because styrene is structurally similar to vinyl chloride, a known mutagen and carcinogen, one can suspect that styrene is potentially mutagenic and possibly carcinogenic. This study demonstrates clearly that styrene oxide is mutagenic to $\mathrm{S}$. typhimurium strains that have been especially constructed to detect mutagens, namely, to TA 1535 and TA 100. These two strains can be used to detect mutagens causing base-pair substitutions, and consequently styrene oxide seems to be a base-pair substitution mutagen. As small an amount as about $10^{-8}$ moles of styrene oxide per plate causes a significiant increase in the mutation rate. Styrene oxide seems to be a directly acting mutagen, because the presence of an enzyme preparation does not enhance its mutagenicity.

Styrene seems to be an indirectly acting mutagen to TA 1535 and TA 100, the same strains which are also sensitive to styrene oxide. One can speculate that styrene oxide, formed by the monooxygenase, is the active principle in the enhanced mutagenesis caused by styrene. However, in tests with TA 100 , styrene also seemed to be a direct mutagen, but, because styrene is rather toxic to Salmonella, the results of certain doses are difficult to interpret.

In the presence of liver homogenate, styrene appears to be even more mutagenic to strain TA 1535 than styrene oxide. This phenomenon is not necessarily in nonagreement with the metabolic activation theory of styrene to corresponding epoxide, but it may be due to the complex factors of chemical/homogenate association. The difference at very low concentrations may be also explained by the presence of an impurity in the styrene preparation. The main impurity, 4-tert.butyl-brenzoatechin, is not, however, mutagenic at all. There is then a possibility that vinylphenol forms perhaps via an epoxide, and it might be the toxic and mutagenic metabolite in bacteria.
While this work was in progress, Milvy and Garro (7) reported the mutagenicity of styrene oxide in S. typhimurium. They found that styrene was unable to increase the mutation rate in the Salmonella strains. They have not, however, tested the mutagenic activity in the presence of liver homogenate, which transforms styrene to its active metabolites. In addition they reported a high spontaneous mutation rate, especially with stnains TA 1535 and TA 100 (7). This high rate may perhaps have been a result of exposure to styrene monomers in the petri dishes used, since we had similar problems with a certain set of petri dishes. After we changed to another type, the spontaneous mutation rate diminished to the normal level.

In conclusion, this study suggests that further, more detailed investigations on the mutagenic and carcinogenic potential of styrene and styrene oxide are warranted and it points to the possible need of an epidemiologic study on workers in industry.

\section{REFERENCES}

1. AMES, B. N., DURSTON, W. E., YAMASAKI, E. and LEE, F. D. Carcinogens are mutagens: A simple test system combining liver homogenates for activation and bacteria for detection. Proc. natl. acad. sci. u.s.a. 70 (1973) 2281-2285.

2 AMES, B. N., LEE, F. D. and DURSTON, W. E. An improved bacterial test system for the detection and classification of mutagens and carcinogens. Proc. natl. acad. sci. u.s.a. 70 (1973) 782-786.

3. AMES, B. N., MC CANN, J. and YAMASAKI, E. Methods for detecting carcinogens and mutagens with the Salmonella/ mammalian-microsome mutagenicity test. Mutat. res. 31 (1975) 347-364.

4. CREECH, J. L. and JOHNSON, M. N. Angiosarcoma of the liver in a vinyl chloride worker. Lancet 1 (1974) 1316-1318.

5. LEIBMAN, K. C. and ORTIZ, E. Oxidation of styrene in liver microsomes. Biochem. pharmacol. 18 (1969) 552-554.

6. MC CANN, J., CHOI, E., YAMASAKI, E. and AMES, B. N. Detection of carcinogens as mutagens in the Salmonella/microsome test: Assay of 300 chemicals. Proc. natl. acad. sci. u.s.a. 72 (1975) 5135-5139.

7. MILVY, P. and GARRO, A. J. Mutagenic activity of styrene oxide (1,2-epoxyethyl- 
benzene), a presumed styrene metabolite. Mutat. res. 40 (1976) 15-18.

8. OESCH, F., JERINA, D. M., DALY, J. W. and RICE, J. M. Induction, activation and inhibition of epoxide hydrase: An anomalous prevention of chlorobenzene-induced hepatotoxicity by an inhibitor of epoxide hydrase. Chem. biol. interact. 6 (1973) $189-202$.

9. RANNUG, U., JOHANSSON, A., RAMEL, C. and WACHTMEISTER, C. A. The mutagenicity of vinyl chloride after metabolic activation. Ambio 23 (1974) 194197.

Received for publication: 1976-07-08 